\title{
Ameliorative Effect of Salicylic Acid on Yield, Biochemical and Antioxidant Parameters of Chickpea (Cicer arietinum L.) under Drought Stress
}

\author{
R.V. Bhutali* and E.P. Lal \\ Department of Biological sciences, Sam Higginbottom University of Agriculture, \\ Technology and Sciences, Allahabad, U. P. India \\ *Corresponding author
}

\begin{tabular}{|l|}
\hline Keyw or d s \\
DAS, Salicylic \\
acid, Ameliorates \\
adverse effects, \\
Chickpea, \\
Flowering, Yield. \\
\hline Article Info \\
\hline $\begin{array}{l}\text { Accepted: } \\
\text { 17 June 2017 } \\
\text { Available Online: } \\
10 \text { August } 2017\end{array}$ \\
\hline
\end{tabular}

A B S T R A C T

Drought stress is one of the major physiological stresses especially in arid and semiarid regions that severely affected crop production meanly leguminous crops. A pot experiment was carried out to assess growth, yield, biochemical and antioxidant contributing characters under semi-controlled environmental condition in the Department of Biological sciences, Sam Higginbottom University of Agriculture Technology and Sciences, Allahabad, India. During November 2016 through March 2017 aiming to alleviate the drought stress effects on chickpea using salicylic acid (SA). Chickpea varieties C1021 and C1022 were used in the experiment. The experiment was conducted using Completely Randomized Design (CRD) in three replications with five levels of drought stress and Salicylic acid concentrations (T0: control, T1: $0.5 \mathrm{mM} \mathrm{SA}+25,50,60$ DAS of irrigation, T2: 1.0mM SA + 25, 65 DAS of irrigation, T3: $1.5 \mathrm{mM} \mathrm{SA}+25,50$ DAS irrigation, T4: $2.0 \mathrm{mM} \mathrm{SA}+25,50 \mathrm{DAS}$ of irrigation), even $0.3 \%$ potassium iodide at anthers formation. Different concentration of SA was applied as foliar spray and spraying was done on 30, 45 and 60 DAS. The data for chlorophyll content in leaf and relative water content (RWC), harvest index, antioxidant like proline, APX, SOD, $\mathrm{H}_{2} \mathrm{O}_{2}$, POD, MDA were observed. Yield and yield contributing characters were measured at maturity. Growth parameter was observed at different intervals of 30,60, 90DAS. The results showed that drought decreased total dry weight, chlorophyll content, relative water content, plant height, number of branches, number of pods/ plant, pod length, 100-seed weight, number of seed/ pod and yield of chickpea. Foliar application of SA was highly significant (T3), then (T2) and then control (T0) of all two varieties best result observed in C1021 and C1022. At different doses under different drought stress conditions had the positive effects related to mitigation of drought stress effect but concentration at i.e., SA @ $1.5 \mathrm{mM}$, respectively were found to alleviate the adverse effects significantly on the above parameters at drought condition.

\section{Introduction}

Chickpea (Cicer arietinum L.) is an important legume crop in the semi-arid tropics of the world. India is the world leader in chickpea production. In India, chickpea is cultivated on 8.68 mha with annual production of $8 \mathrm{mt}$ and an average yield of 844 kgha-1.17 However, it is under heavy stresses due to various abiotic factors that results in yield losses. The present study was performed to investigate the response of chickpea plants to exogenous application of SA and to examine the effect of SA on drought stress the activities of 
antioxidant enzymes (POD), hydrogen peroxide and total proteins in this crop, since these are the most studied components implicated in plant defence against abiotic stresses.

Drought stress is a major abiotic stress limiting agricultural crop production worldwide. Plants respond to drought stress and acclimatize through various physiological and biochemical changes (Farooq et al., 2009). Drought induces oxidative stress in plants, in which reactive oxygen species (ROS), hydrogen peroxide $\left(\mathrm{H}_{2} \mathrm{O}_{2}\right)$. Oxidative damage in the plant tissue is alleviated by a concerted action of both enzymatic and nonenzymatic antioxidant metabolism (Hasegava et al., 2000). These mechanisms include $\beta$ carotenes, and enzymes including superoxide dismutase (SOD), peroxidase (POX), ascorbate peroxidase (APX) (Prochazkova et al., 2001). Plants experience drought stress either when the water supply to roots is interrupted or when transpiration rate becomes very high. These two conditions often coincide under arid and semiarid climates. Salicylic acid (SA) is a naturally existing phenolic compound. Evidences put forward that externally applied SA increased plant's tolerance to several abiotic stresses, including drought (Azooz and Youssef, 2010). Exogenous SA reduced transpiration and increased nitrate reductase activity, flower longevity as well as the yield of some plants (Raskin, 1992), which overall suggest that SA may enhance the multiple types of stress tolerance in plants through which interactive effects on several functional molecules or other signaling molecules participating in more complex stress responses. Drought stress is a major concern affecting the agriculture production. Generally, pulses are very susceptible to drought stress. Chickpea (Cicer arietinum L.) is the third most important grain legume crop in the world experiences water stress during pod set and seed filling stage (terminal drought) in India and the Mediterranean basin, leading to a substantial yield loss (Turner et al., 2001). Drought stress during seed filling has been reported to be highly detrimental to yield in chickpea (Davis et al., 1999). Comparatively meagre work is on record regarding role of SA on drought tolerance in chickpea. SA appears to have innate potentiality for increasing antioxidants and influencing antioxidant enzyme activity in plants subjected to oxidative stress (Hayat et al., 2008). Therefore, the present investigation was conducted to evaluate the drought stress ameliorating ability of SA with special emphasis on growth and antioxidant system in drought stressed chickpea plants.

\section{Materials and Methods}

A pot experiment was carried out during rabi season of 2016-2017 at Department of Biological Sciences, SHUATS, Allahabad (U.P.).The experiment was laid out in CRD design with five treatments with three replications for present investigation and out of 2 varieties of chickpea, 3 plants will be tagged randomly for the purpose of morphological, physiological/biochemical studies. Treatments will be denoted as T0, T1, $\mathrm{T} 2, \mathrm{~T} 3$ and T4 replications as R1, R2 and R3 for variety $\mathrm{C} 1021$ and for variety $\mathrm{C} 1022$ treatment will be denoted as F0, F1, F2, F3, and F4 replication as R1, R2 and R3.

Spraying of potassium iodide @ 0.3g at anther formation in chickpea

\section{Estimation of biochemical parameter}

\section{Estimation of total chlorophyll content}

Chlorophyll was determined according to Wellborn (1983). One gram leaves sample was weighed and crushed with $80 \%$ acetone made the volume to $10 \mathrm{ml}$ with $80 \%$ acetone, 
centrifuged at $800 \mathrm{ppm}$ for 5 minute. The supernatant was read under 663, 645 nanometre. The readings were fed in the following formula and results were determined under spectrophotometer.

\section{Carotenoid content}

Carotenoid was determined according to Wellborn. (1983). $0.5 \mathrm{gm}$ and homogenized in $10 \mathrm{ml}$ of acetone (80\% acetone), next to the centrifuged at $3000 \mathrm{rpm}$ at $10 \mathrm{~min}$. The absorbance was recorded at $470 \mathrm{~nm}$.

Determination of total protein was estimated from seed by Lowry's method (Lowry et al., 1951)

\section{Reagents preparation}

\section{Reagent A}

Prepared by dissolving 2\% Sodium carbonate in $0.1 \mathrm{~N}$ Sodium hydroxide.

\section{Reagent B}

Prepared by dissolving equal amount of $1 \%$ copper sulphate and $2.0 \%$ of potassium sodium tartarate.

\section{Reagent C}

Prepared by mixing $50 \mathrm{ml}$ reagent $\mathrm{A}$ and $1 \mathrm{ml}$ reagent $\mathrm{B}$ and it was freshly prepared before use.

\section{Reagent D}

Folin - Ciocalteu reagent available commercially was used after $1: 1, \mathrm{v} / \mathrm{v}$ dilution with distilled water.

\section{Estimation of protein standard}

Estimation of protein was done by pipetting out $50 \mu \mathrm{l}$ supernatant containing proteins into test tubes in replicates of three and the total volume was made up to $1 \mathrm{ml}$. A tube with 1 $\mathrm{ml}$ distilled water served as a blank. $3 \mathrm{ml}$ reagent $\mathrm{C}$ was added to each tube including the blank and after proper mixing the solution were allowed to stand for $30 \mathrm{~min}$ then $0.5 \mathrm{ml}$ reagent $\mathrm{D}$ was added and after mixing, the tubes were left at room temperature in the dark for $60 \mathrm{~min}$. Blue colour was developed in the solution. The absorbance was taken at $660 \mathrm{~nm}$ in UV- visible spectrophotometer.

\section{Determination of proline}

Proline content was determined by the method adopted by Bates et al., (1973). 0.5g of flesh leaf sample was homogenized in $10 \mathrm{ml}$ of 3\% aqueous sulphosalicylic acid and the homogenate was filtered using what man's No.1 filter paper. Two ml filtrate was taken in a test tube and $2 \mathrm{ml}$ of acid ninhydrin and $2 \mathrm{ml}$ of glacial acetic acid was added. This was allowed to react for 1 hour at $100^{\circ} \mathrm{c}$ in a boiling water bath. The reaction was terminated by placing the tube in an ice box. 4 $\mathrm{ml}$ of was added to the reaction mixture. The chromophore containing toluene was separated and absorbance was recorded at 520 $\mathrm{nm}$ wavelength using toluene as blank.

\section{Determination of Hydrogen Peroxide $\left(\mathrm{H}_{2} \mathrm{O}_{2}\right)$}

To estimate the hydrogen peroxide, content the method given by Velikovo et al., (2000) was used in this present investigation.500 $\mathrm{mg}$ of leaf tissue was homogenated with $5.0 \mathrm{ml}$ of Trichloro Acetic acid (TCA) and cooled immediately in ice bath. Then it is centrifuged at $12000 \mathrm{~g}$ for $15 \mathrm{~min}$ and the supernatant was collected. $0.5 \mathrm{ml}$ of supernatant was transferred to test tube and $0.5 \mathrm{ml}$ of $10 \mathrm{mM}$ phosphate buffer (pH 7.0) AND $1.0 \mathrm{ml}$ of potassium iodide $(1 \mathrm{M})$ were added. After the addition, the solution was mixed vigorously and the absorbance was recorded at $390 \mathrm{~nm}$. $\mathrm{H}_{2} \mathrm{O}_{2}$ content was determined by using an 
extinction coefficient (E) of $0.28 \mu \mathrm{m}^{-1} \mathrm{~cm}^{-1}$ and expressed as $n \mathrm{~mol} \mathrm{~g}^{-1} \mathrm{fw}$.

\section{Determination of peroxidase determination}

Phosphate buffer $100 \mathrm{mM}$.

Solution A: - contains $6.8 \mathrm{~g}$ of $\mathrm{KH}_{2} \mathrm{PO}_{4}$ in 500 $\mathrm{ml}$ of distilled water.

Solution B: - contains $8.71 \mathrm{~g}$ of $\mathrm{K}_{2} \mathrm{HPO}_{4}$ in $500 \mathrm{ml}$ of distilled Water.

Phosphate buffer was prepared by mixing 87 $\mathrm{ml}$ of solution A and $15 \mathrm{ml}$ of solution B. And the $\mathrm{pH}$ was set to 6.1.It was prepared by dissolving $124 \mu \mathrm{l}$ of $30 \% \mathrm{H}_{2} \mathrm{O}_{2}\left(30 \mathrm{ml} \mathrm{H}_{2} \mathrm{O}_{2}\right.$ in $70 \mathrm{ml} \mathrm{DW}$ ) in distilled water where the final volume was made up to $100 \mathrm{ml}$.Guaicol $(96 \mathrm{mM})$ was prepared by dissolving $1075 \mu 1$ of guaicol in distilled water, where the final volume was made up to $100 \mathrm{ml}$.

The reaction mixture was prepared by adding $1.0 \mathrm{ml}$ of phosphate buffer, $0.5 \mathrm{ml}$ of guaicol, and $0.5 \mathrm{ml}$ of $\mathrm{H}_{2} \mathrm{O}_{2}, 0.1 \mathrm{ml}$ of crude enzyme and $0.9 \mathrm{ml}$ of distilled water. And the absorbance was measured at $470 \mathrm{~nm}$.

\section{Determination of Ascorbate peroxidase determination (APX)}

Ascorbate peroxidase is one of the most widely distributed antioxidant enzyme which reduce hydrogen peroxide to water using reduced ascorbate as the electron donor. It plays a more important role in scavenging ROS than other antioxidative enzyme since ascorbate, in addition to reacting with $\mathrm{H}_{2} \mathrm{O}_{2}$ may react with superoxide, singlet oxygen and hydroxyl radical.

\section{Reagents}

$100 \mathrm{mM}$ potassium phosphate buffer $(\mathrm{pH}$ 7.0), $15 \mathrm{mM} \mathrm{L}$-ascorbate, $10 \mathrm{mM} \mathrm{H}_{2} \mathrm{O}_{2}$

APX is assayed by the method of Nakano and Asada (1981)
1. Set up a reaction mixture $(3.0 \mathrm{ml})$ by adding $2.7 \mathrm{ml}$ of $100 \mathrm{mM}$ potassium phosphate buffer ( $\mathrm{pH}$ 7.0). $0.1 \mathrm{ml} \mathrm{L-ascorbate}$ and $0.15 \mathrm{ml} \mathrm{H}_{2} \mathrm{O}_{2}$.

2. Initiate the reaction by adding $50 \mu 1$ of enzyme extract and record the decrease in absorbance at $290 \mathrm{~nm}$ spectrophotometrically for 2 min against blank which corresponds to the oxidation of ascorbic acid.

3. Calculation the enzyme activity using the molar extinction coefficient of $2.8 \mathrm{mM}^{-1} \mathrm{~cm}^{-1}$ for ascorbate. One enzyme unit is expressed as the amount required to oxidize one $\mathrm{n}$ mole of ascorbate $\min ^{-1}$

\section{Determination of Superoxide Dismutase (SOD)}

Because of the instability of its substrate, all available assays of superoxide dismutase are indirect and depend upon its ability to scavenge $\mathrm{O}_{2}$ from reaction mixture and thus to inhibit the reaction caused by $\mathrm{O}_{2}$. In one of the methods, superoxide dismutase was quantitated on the basis of its ability to inhibit photochemical reduction of nitro- blue tetrazolium (NBT).

\section{Reagents}

Methionine 300g of methionine (mol.wt.150) in $100 \mathrm{ml}$ of double distilled water

Riboflavin solution $(75 \mu \mathrm{M})$

Dissolve $28.5 \mathrm{mg}$ riboflavin (mol. wt. 376)

Nitro -blue tetrazolium solution $(1.125 \mathrm{mM})$

Dissolve $46 \mathrm{mg}$ of NBT (mol. wt. 817) in 50 $\mathrm{ml}$ of double distilled water

EDTA disodium solution (1.5mM)

Dissolve $56 \mathrm{mg}$ of EDTA - disodium salt (mol. wt. 372) in $100 \mathrm{ml}$ of double distilled water. 
Phosphate buffer (50 Mm; pH 7.0)

Dissolve $0.265 \mathrm{~g}$ of $\mathrm{KH}_{2} \mathrm{PO}_{4}$ (mol. wt. 174) in $50 \mathrm{ml}$ of distilled water. Adjust the $\mathrm{Ph}$ to 7.0, if there is need to do so, and make up the volume to $100 \mathrm{ml}$ with distilled water.

Phosphate buffer (50Mm: pH 7.8).

Dissolve $0.058 \mathrm{~g}$ of $\mathrm{KH}_{2} \mathrm{PO}_{4}$ (mol.wt.136) and 0.8 of $\mathrm{K}_{2} \mathrm{HPO}_{4}$ (mol.wt.174) in $50 \mathrm{ml}$ of distilled water. Adjust the $\mathrm{pH}$ to 7.0 , if there is need to do so, and make up the volume to $100 \mathrm{ml}$ with distilled water.

\section{Results and Discussion}

The various morphological, yield, biochemical and antioxidant characters studied and portrayed in different figures have been described in this chapter.

\section{Growth parameters}

Among all the two variety $\mathrm{C} 1021$ and $\mathrm{C} 1022$ the plant height $(\mathrm{cm})$ at 30DAS, 60DAS, 90DAS and No. of primary branches was maximum in $\mathrm{C} 1022$ in $\mathrm{T} 3$ (salicylic acid concentration $1.5 \mathrm{mM}$ ) followed by $\mathrm{C} 1021$ in T3 (salicylic acid concentration $1.5 \mathrm{mM}$ ). In case of the relative water content it was found maximum in variety C1021 in T3 (salicylic acid concentration $1.5 \mathrm{mM}$ ) followed by variety $\mathrm{C} 1022$ in $\mathrm{T} 3$ (salicylic acid concentration $1.5 \mathrm{mM})$.

\section{Yield parameters}

Among all the two variety $\mathrm{C} 1021$ and $\mathrm{C} 1022$ in all treatment the number of pods/plant, seed weight per pod, seed yield per plant, 100-seed weight and harvest index was greater in variety $\mathrm{C} 1022-47.83$ pods in $\mathrm{T} 3$ (salicylic acid concentration $1.5 \mathrm{mM}$ ) followed by C1021- 46.33 in T3 (salicylic acid concentration $1.5 \mathrm{mM}$ ).

\section{Bio chemical parameters}

Among all the two variety C1021 and C1022 at 60 DAS the maximum chlorophyll a was observed in C1021 in T3 (salicylic acid concentration $1.5 \mathrm{mM}$ ) followed by $\mathrm{C} 1022$ in T3 (salicylic acid concentration $1.5 \mathrm{mM}$ ).

Table.1 Treatment details

\begin{tabular}{|l|l|l|l|l|ll|}
\hline Treatment & Chemical & Concentration & $\begin{array}{l}\text { Irrigation } \\
\text { days }\end{array}$ & Spray & $\begin{array}{l}\text { Spraying } \\
\text { DAS }\end{array}$ \\
\hline T0 & Control & --------- & Well irrigated & ------ & ----- & \\
\hline T1 & Salicylic acid & $0.5 \mathrm{mM}$ & $25,50,60$ DAS & foliar & $\begin{array}{l}30,45 \\
60\end{array}$ & and \\
\hline T2 & Salicylic acid & $1.0 \mathrm{mM}$ & 25,65 DAS & foliar & $\begin{array}{l}30,45 \\
60\end{array}$ & and \\
\hline T3 & Salicylic acid & $1.5 \mathrm{mM}$ & 25,50 DAS & foliar & $\begin{array}{l}30,45 \\
60\end{array}$ \\
\hline T4 & Salicylic acid & $2.0 \mathrm{mM}$ & 25,50 DAS & foliar & $\begin{array}{l}30,45 \\
60\end{array}$ & and \\
\hline
\end{tabular}


Fig.1 Effect of drought stress and salicylic acid on plant height (30,60,90DAS), No. of primary branches, No. of pod /plant, seed weight/plant, seed weight/pod, 100 seed weight,

Harvest index \%, RWC in variety $\mathrm{C} 1022$

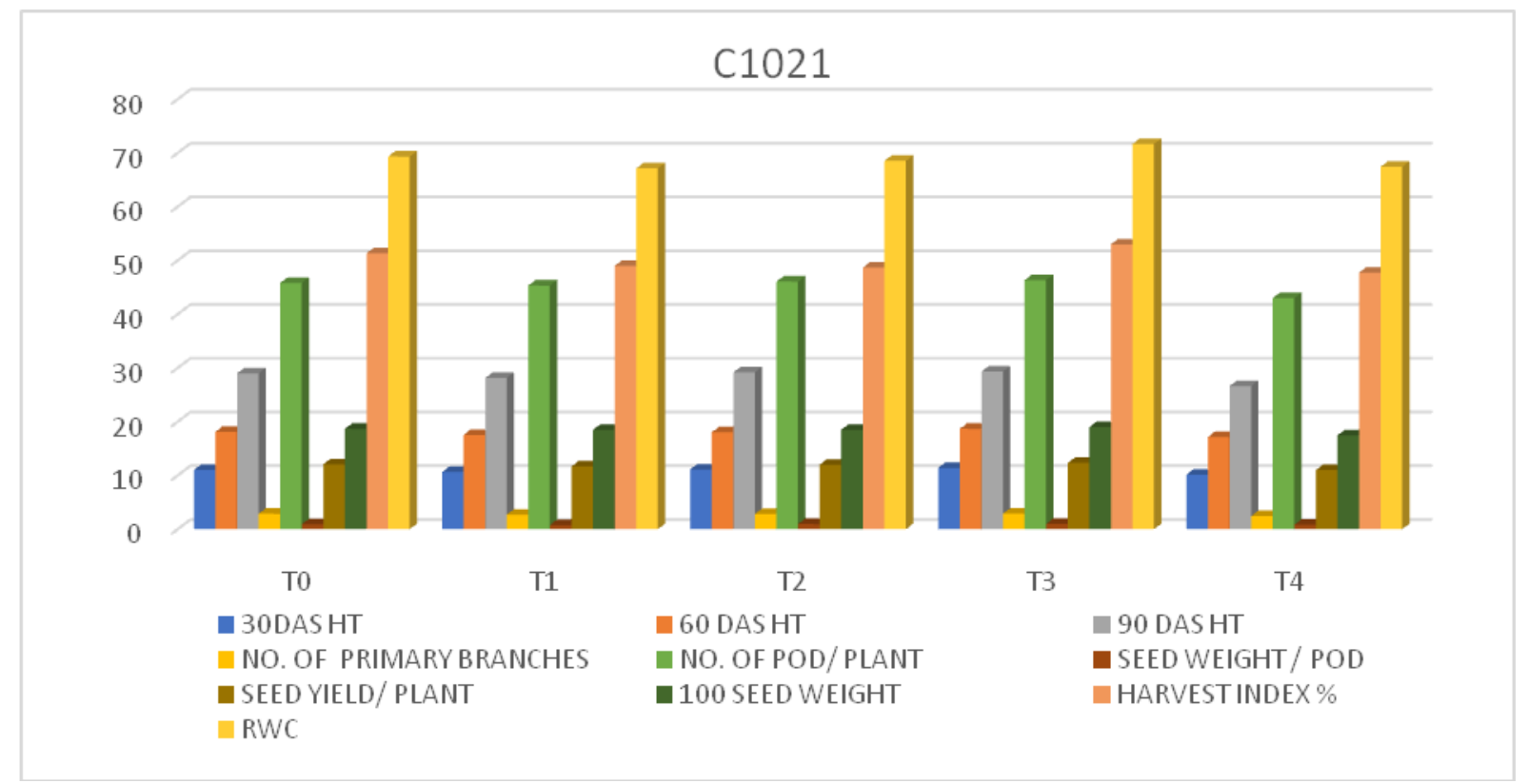

Fig.2 Effect of drought stress and salicylic acid on plant height (30,60,90DAS), No. of primary branches, No. of pod /plant, seed weight/plant, seed weight/pod, 100 seed weight,

Harvest index \%, RWC in variety $\mathrm{C} 1021$

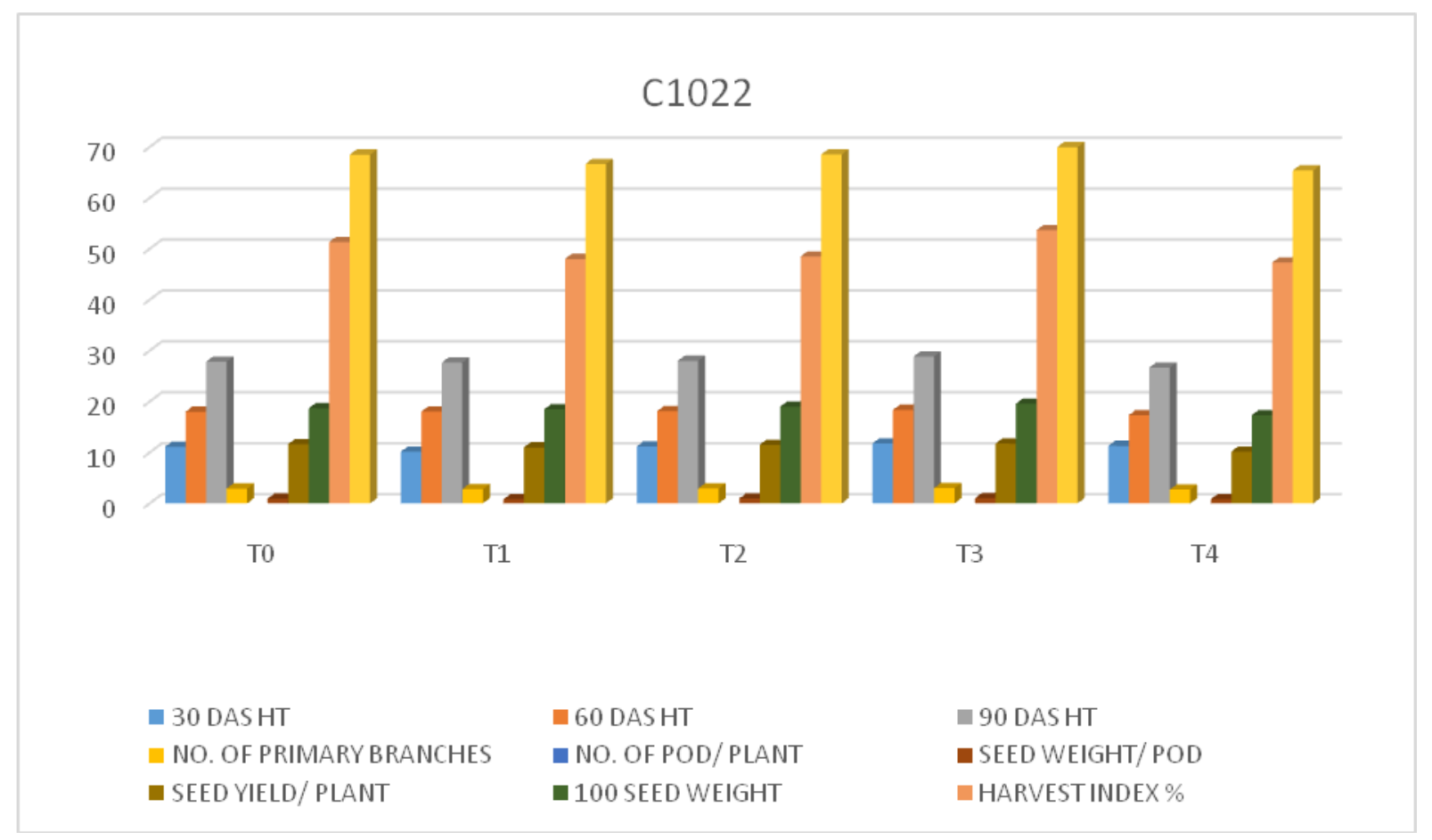


Fig.3 Effect of drought stress and salicylic acid on Chlorophyll a (60,90DAS), Chlorophyll b (60,90DAS), Total Chlorophyll (60,90DAS), Carotenoids (60,90DAS) in C1021

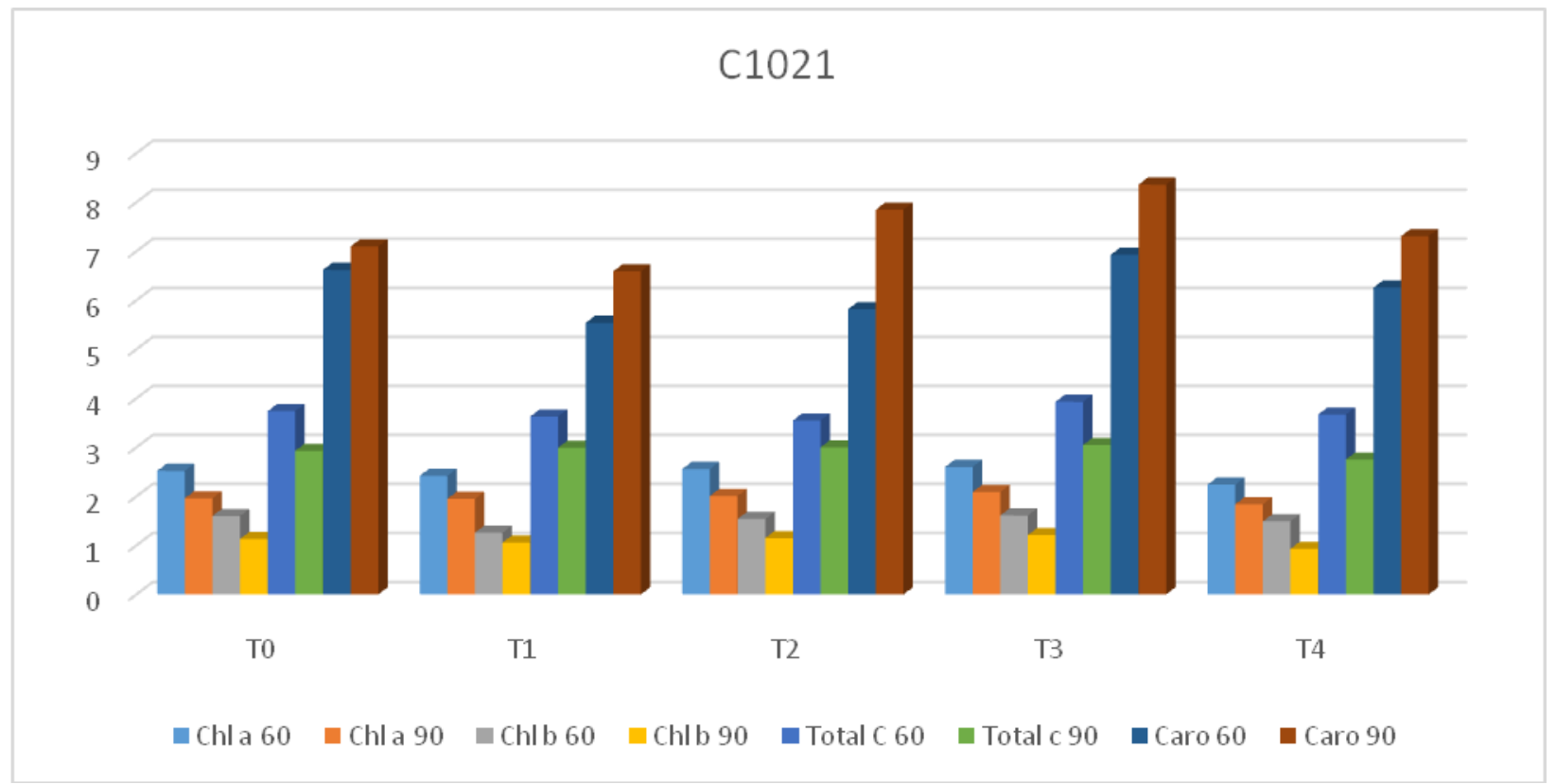

Fig.4 Effect of drought stress and salicylic acid on Chlorophyll a (60,90DAS), Chlorophyll b (60,90DAS), Total Chlorophyll (60,90DAS), Carotenoids (60,90DAS) in C1022

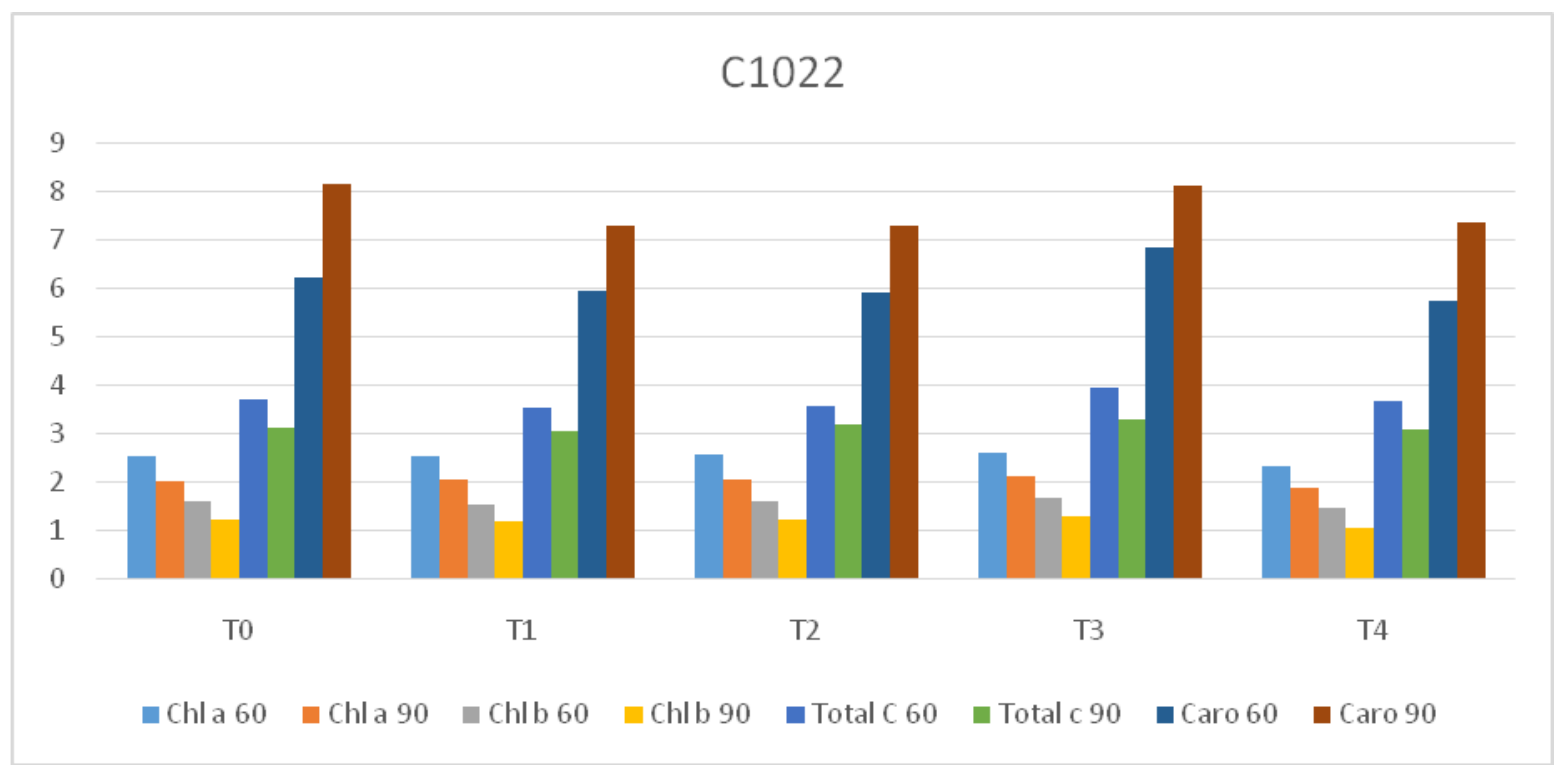


Fig.5 Effect of drought stress and salicylic acid on protein content in chickpea varieties, antioxidant

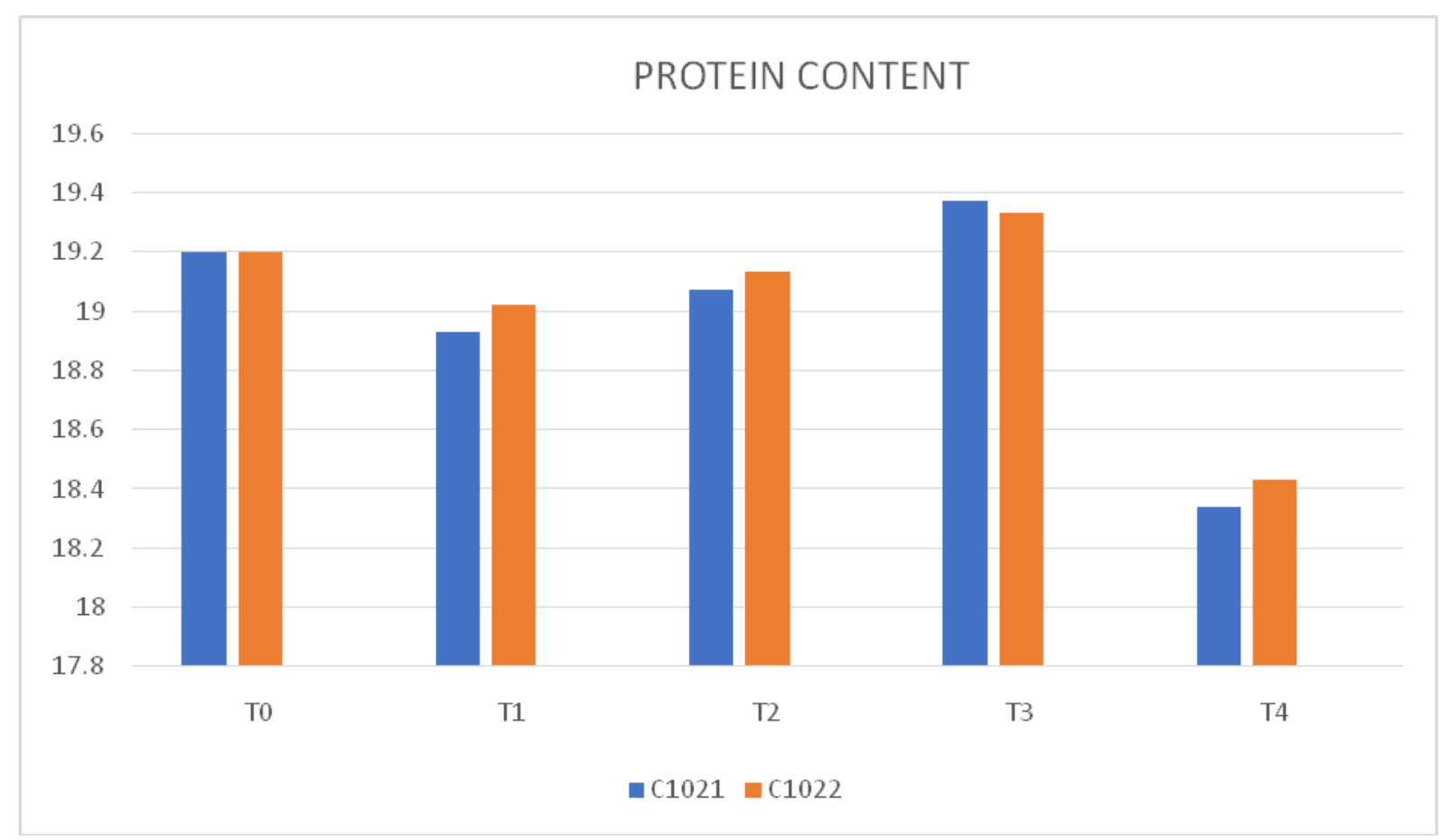

Fig.6 Effect of drought stress and salicylic acid on proline in chickpea varieties

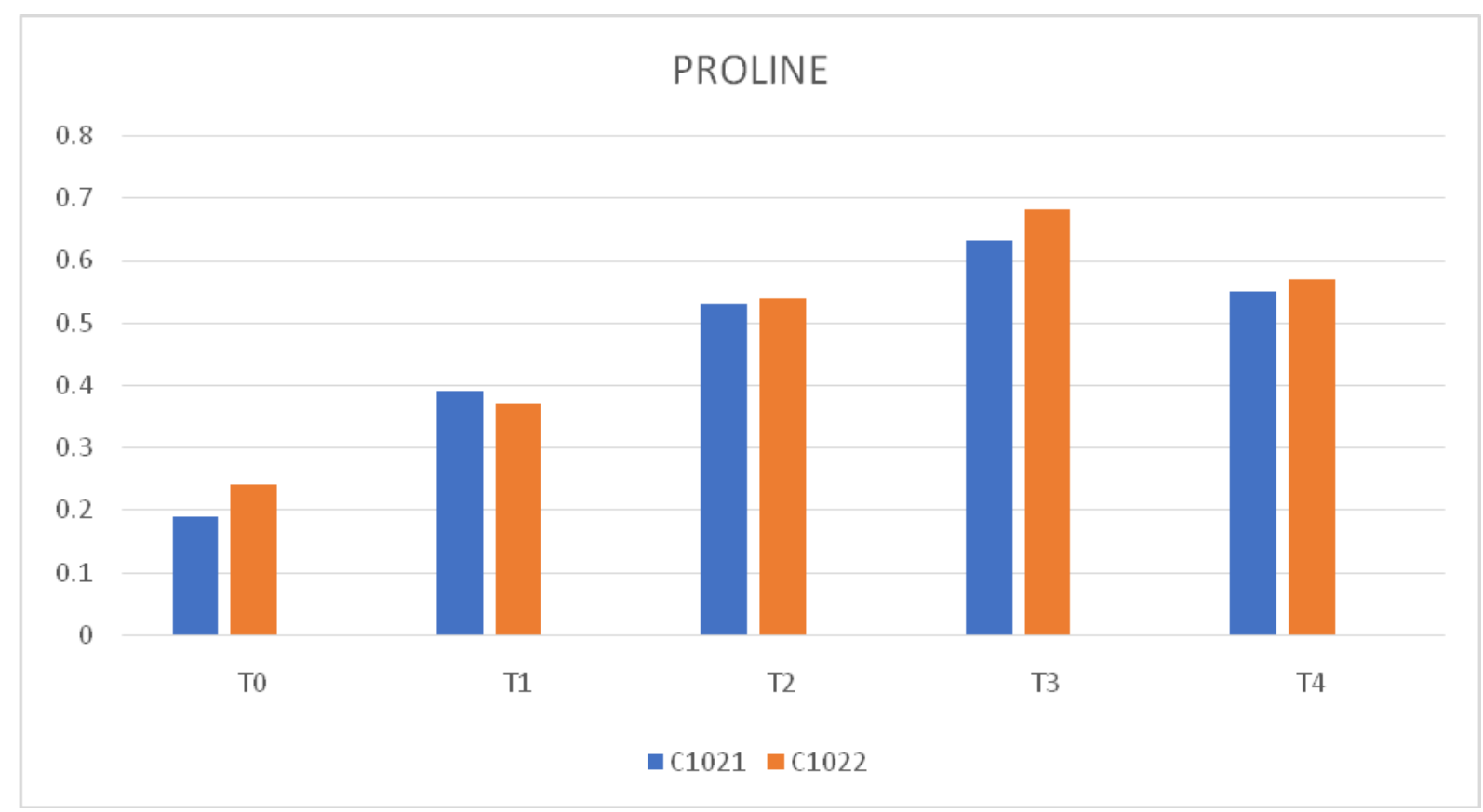


Fig.7 Effect of drought stress and salicylic acid on ascorbate peroxidase in chickpea varieties

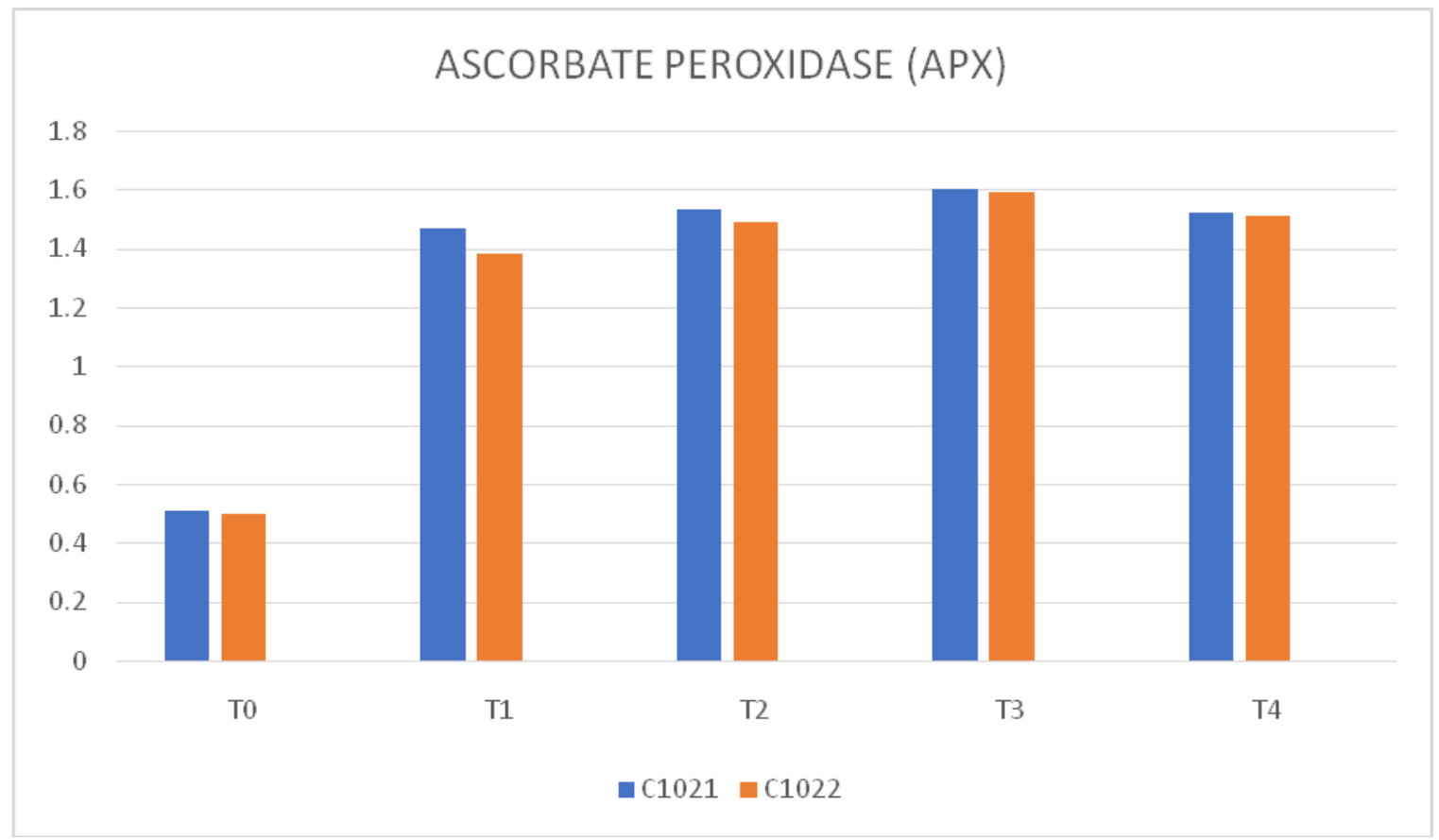

Fig.8 Effect of drought stress and salicylic acid on hydrogen peroxide in chickpea varieties

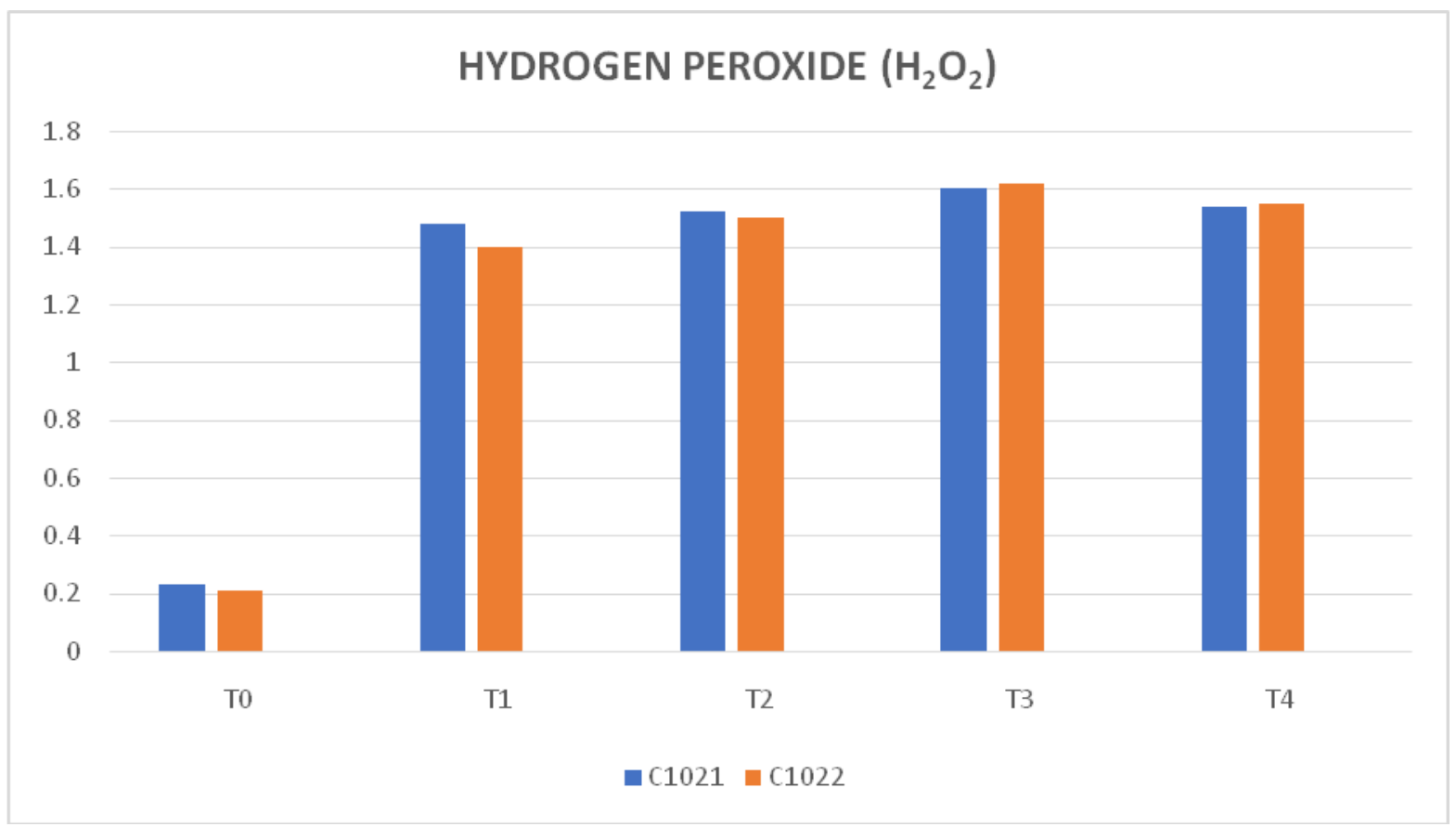


Fig.9 Effect of drought stress and salicylic acid on peroxidase in chickpea varieties

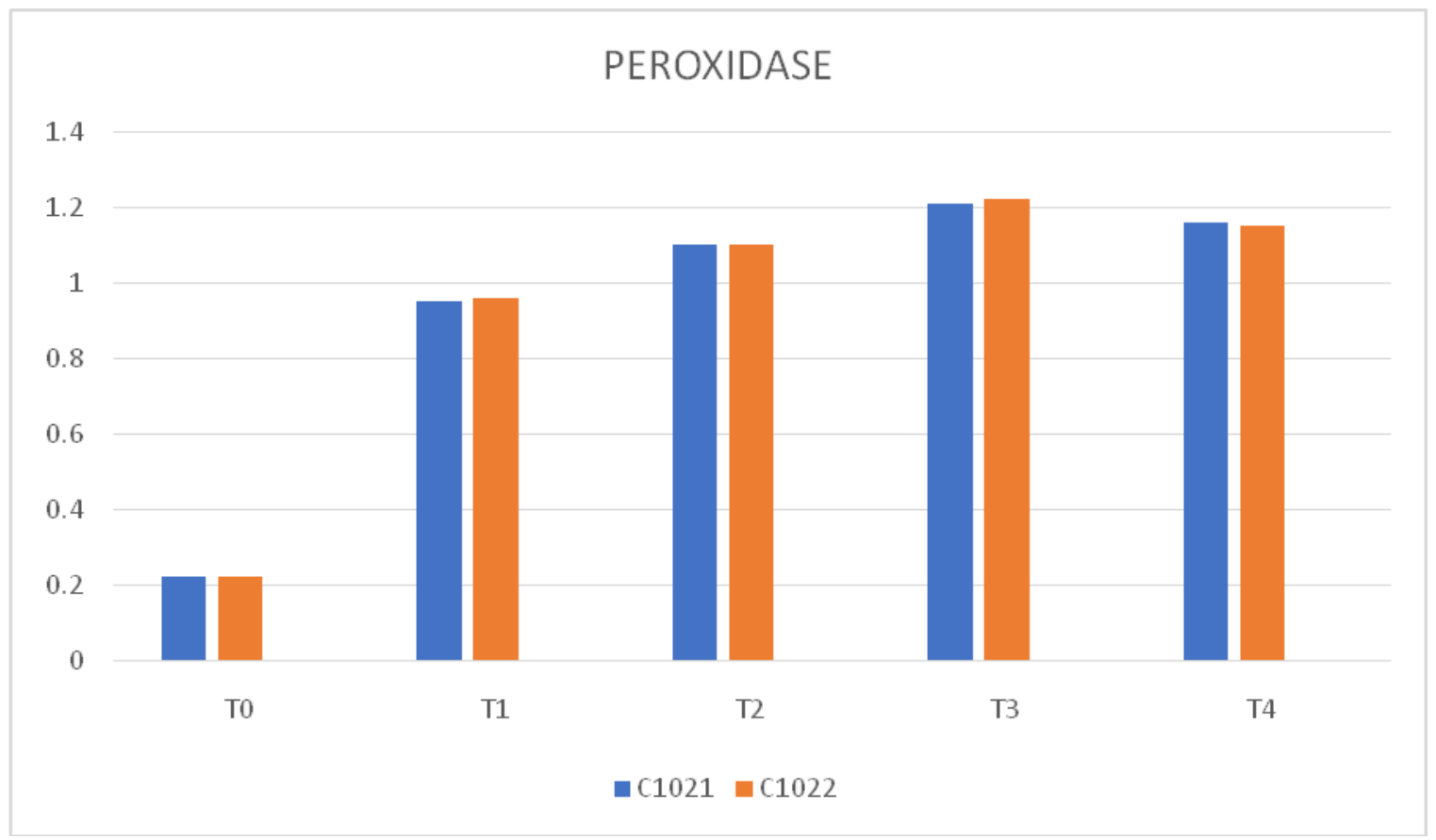

Fig.10 Effect of drought stress and salicylic acid on super oxide dismutase in chickpea varieties

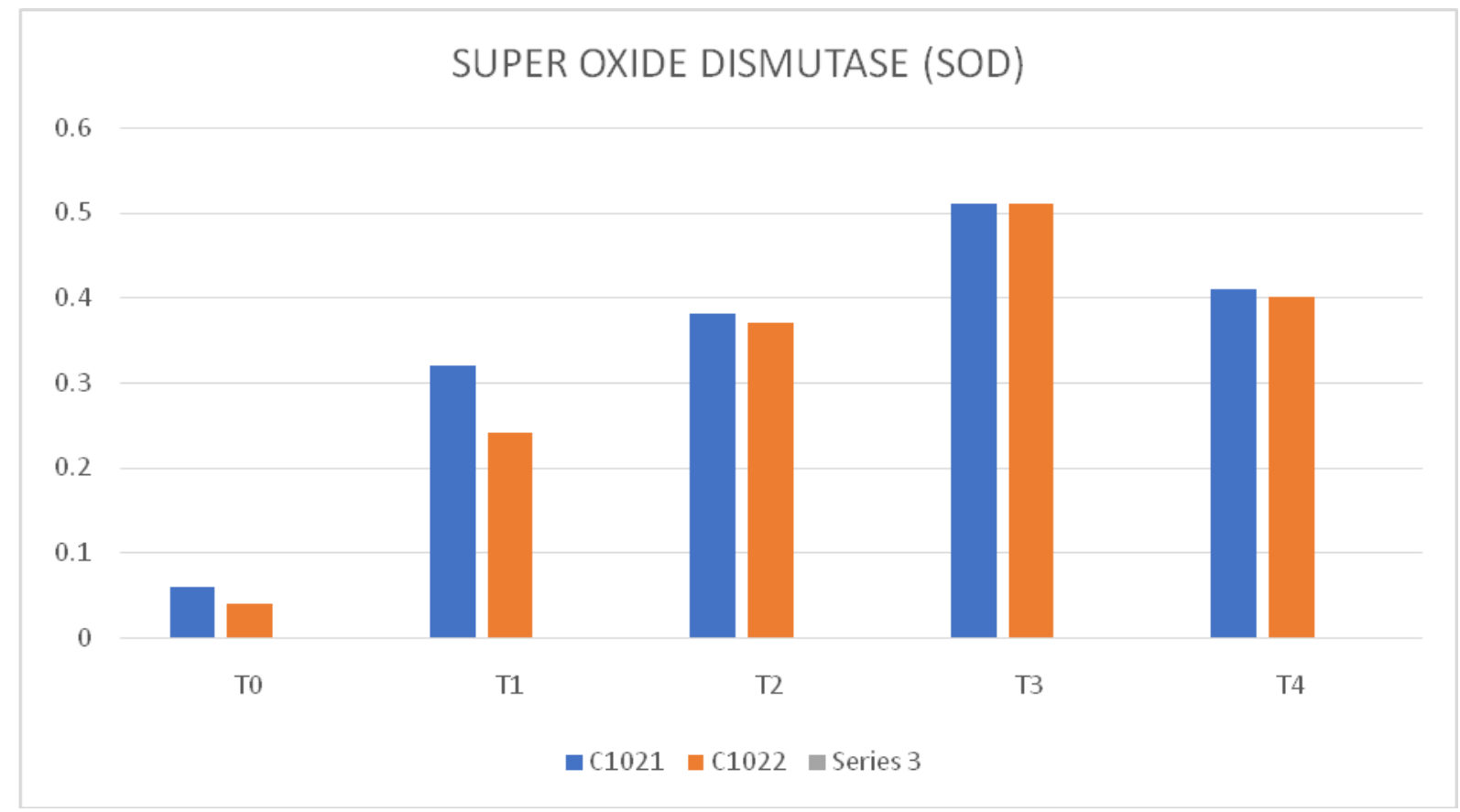

In case of 90 DAS the maximum chlorophyll a was observed in variety $\mathrm{C} 1022$ in $\mathrm{T} 3$ (salicylic acid concentration $1.5 \mathrm{mM}$ ) followed by variety $\mathrm{C} 1021$ in $\mathrm{T} 3$ (salicylic acid concentration $1.5 \mathrm{mM})$. In 60 DAS the maximum chlorophyll $b$ was observed in 
variety $\mathrm{C} 1022$ in $\mathrm{T} 3$ (salicylic acid concentration $1.5 \mathrm{mM}$ ) and followed by in $\mathrm{T} 3$ (salicylic acid concentration $1.5 \mathrm{mM}$ ). In case of 90DAS was maximum in C1022 in T3 (salicylic acid concentration $1.5 \mathrm{mM}$ ) followed by $\mathrm{C} 1021$ in T3 (salicylic acid concentration $1.5 \mathrm{mM})$. At 6DAS the maximum total chlorophyll 60 DAS was observed in both the variety C1021 and C1022 of treatment T3 (salicylic acid concentration $1.5 \mathrm{mM}$ ) followed by the variety $\mathrm{C} 1021$ in T0 (control). In case of 90 DAS the maximum total chlorophyll was observed in variety $\mathrm{C} 1022$ in $\mathrm{T} 3$ (salicylic acid concentration $1.5 \mathrm{mM}$ ).

Maximum carotenoid at 60DAS was observed in variety C1021 in T3 (salicylic acid concentration $1.5 \mathrm{mM}$ ) followed by $\mathrm{C} 1022$ in T3 (salicylic acid concentration $1.5 \mathrm{mM}$ ). In case 90DAS was observed in variety $\mathrm{C} 1021$ in T3 (salicylic acid concentration $1.5 \mathrm{mM}$ ) followed by C1022 T3 (salicylic acid concentration $1.5 \mathrm{mM}$ ).

In protein content it was observed in C1021 in T3 (salicylic acid concentration $1.5 \mathrm{mM}$ ) followed by $\mathrm{C} 1022$ in T3 (salicylic acid concentration $1.5 \mathrm{mM}$ ). In case of proline maximum was found in $\mathrm{C} 1022$ in $\mathrm{T} 3$ (salicylic acid concentration $1.5 \mathrm{mM}$ ) followed by $\mathrm{C} 1021$ in T3 (salicylic acid concentration $1.5 \mathrm{mM})$.

In case of APX it was observed in C1021 in T3 (salicylic acid concentration $1.5 \mathrm{mM}$ ) followed by $\mathrm{C} 1022$ in $\mathrm{T} 3$ (salicylic acid concentration $1.5 \mathrm{mM}$ ).

In case of $\mathrm{H}_{2} \mathrm{O}_{2}$ was observed in $\mathrm{C} 1022$ in $\mathrm{T} 3$ (salicylic acid concentration $1.5 \mathrm{mM}$ ) followed by $\mathrm{C} 1021$ in T3 (salicylic acid concentration $1.5 \mathrm{mM})$ and maximum peroxidase was observed in variety C1022- in T3 (salicylic acid concentration $1.5 \mathrm{mM}$ ) followed by C1021 in T3 (salicylic acid concentration $1.5 \mathrm{mM})$. In case of SOD it was observed maximum in the both variety $\mathrm{C} 1021-0.51$ in T3 (salicylic acid concentration $1.5 \mathrm{mM}$ ) and C1021- 0.51 in T3 (salicylic acid concentration $1.5 \mathrm{mM}$ ).

\section{Protein content}

The effect of different concentration of Salicylic acid applied on chickpea crop was studied by protein content in varieties $\mathrm{C} 1021$ and C1022.

\section{Proline}

The effect of different concentration of Salicylic acid applied on plants was studied on Chickpea plant proline in varieties C1021 and $\mathrm{C} 1022$.

\section{Ascorbate peroxidase (APX)}

The effect of different concentration of Salicylic acid applied on plants was studied on Chickpea plant ascorbate peroxidase (APX) in varietiesC1021 andC1022.

\section{Hydrogen peroxide $\left(\mathrm{H}_{2} \mathrm{O}_{2}\right)$}

The effect of different concentration of Salicylic acid applied on plants was studied on Chickpea plants, Hydrogen peroxide $\left(\mathrm{H}_{2} \mathrm{O}_{2}\right)$ in varieties $\mathrm{C} 1021$ and $\mathrm{C} 1022$.

\section{Peroxidase}

The effect of different concentration of Salicylic acid applied on plants was studied on Chickpea plants, Peroxidase in variety C1021 and C1022.

\section{Super Oxide Dismutase (SOD)}

The effect of different concentration of Salicylic acid applied on plants was studied on Chickpea plants, Super Oxide Dismutase (SOD) in variety C1021 and C1022. 
In conclusion, based on present study, it was concluded that drought stress was deleterious to chickpea growth and yield. The result shows that C1021 T3 (salicylic acid concentration $1.5 \mathrm{mM}$ ) showed superior adoptive traits and yield $(12.17 \mathrm{~g} / \mathrm{seed} /$ plant $)$. Among two varieties (C1021 and C1022) and the treatment T3 (salicylic acid concentration $1.5 \mathrm{mM}$ ) were found to show higher ameliorating effect with yield $(11.74 \mathrm{~g} / \mathrm{seed} / \mathrm{plant}$ in $\mathrm{C} 1022)$ than other treatments under drought stress and the T2 (salicylic acid concentration $1.0 \mathrm{mM}$ ) also showed good result and T4 (salicylic acid concentration $2.0 \mathrm{mM}$ ) treatment. The exogenous application of SA (salicylic acid) improved the flowering, yield, biochemical and antioxidant parameters by decreasing the harmful effect of drought stress.

\section{References}

Patel, P.K. and Hemantaranjan, A. and Sarma, B. 2013. Effect of salicylic acid on growth and metabolism of chickpea (Cicer arietinum L.) under drought stress, ResearchGate, Vol.17, 151-157.

Dianat, M., Jamal Mohammad, S. and Tavassolian, I. 2016. Salicylic acid mitigates drought stress in Lippia citriodra L. Effect on biochemical traits and essential oil yield. Biocatalysis and Agri. Biotechnol., 8: Vol-8: 286-293

Vaisnad, S. and Talebi, R. 2015. Salicylic acid enhanced morphological and physiological responses in chickpea (Cicer arietinum) under water deficit stress. Environ. Experimental Biol., 109-115.

Nezhad, T.A., Mobasser, H.R., Mehdi, D. and
Karimian, M. 2014. Effect of foliar application of salicylic acid and drought stress on quantitative yield of mungbean (Vigna radiata L.). J. Novel Appl. Sci., 512515.

Aldesuquy, H.H. 2014. Effect of salicylic acid induced modification in water relation and productivity of drought wheat plant. $J$. Stress Physiol. Biochem., 10(2): 55-73.

FAO. 2009. Production year book. Food and Agriculture Organization for the United Nations, Rome Italy.

Hayat, Q., Hayat, S., Alyemeni, M.N. and Ahmad, A. 2012. Salicylic acid mediated changes in growth, photosynthesis, nitrogen metabolism and antioxidant defense systemin Cicer arietinum L. Plant Soil Environ., 58(9): 417-423.

Palma, F., Lopez-Gomez, M., Tejera, N.A., Lluch, C. 2013. Salicylic acid improves the salinity tolerance of Medicago sativa in symbiosis with Sinorhizobium meliloti by preventing nitrogen fixation inhibition, Plant Sci., 208: 75-82.

Iqbal, M., Khan, R., Fatma, M., Per, T.S., Anjum, N.A. and Khan, A. 2015. Salicylic acidinduced abiotic stress tolerance and underlying mechanisms in plants. Frontiers in Plant Sci., 114-110.

Noreen, S., Fatima, K., Athar, H.U.R., Ahamad, S. and Hussain, K. 2017. Enhancement of physio-biochemical parameters of wheat through exogenous application of salicylic acid under drought stress. J. Animal and Plant Sci., 7(1): 153-163.

Semida, W.M., Abd El-Mageed, Mohamed, T.A. and Sawah, N.A. 2016. Combined effect of deficit irrigation and foliar applied salicylic acid on physiological responses, yield, and water-use efficiency of onion plants in saline calcareous soil. Arch. Agron. Soil Sci., 1-13.

\section{How to cite this article:}

Bhutali, R.V. and Lal, E.P. 2017. Ameliorative Effect of Salicylic Acid on Yield, Biochemical and Antioxidant Parameters of Chickpea (Cicer arietinum L.) under Drought Stress. Int.J.Curr.Microbiol.App.Sci. 6(8): 1388-1399. doi: https://doi.org/10.20546/ijcmas.2017.608.169 